Resenhas 



\title{
Naipaul, V. S. A máscara da África: vislumbres das crenças africanas. Tradução: Marcos Bagno. São Paulo: Companhia das Letras, 2011. 288 p.
}

\author{
Julio Pimentel Pinto
}

A máscara da África consegue agradar, paradoxalmente, a defensores e detratores de V. S. Naipaul, escritor trinitário que ganhou o Nobel de Literatura de 2001.

É fácil de entender.

Para aqueles que acusam Naipaul de enxergar o mundo com olhos europeizados, de reproduzir visões e noções externas acerca da vida e dos rituais sociais em países pobres, o livro é uma nova oportunidade de reafirmar a distância que o autor mantém dos mundos que visita e relata.

Para quem considera Naipaul um dos poucos grandes escritores dos dias de hoje, a narrativa reúne algumas das principais qualidades de sua escrita: o texto fluido, conciso e bem construído, a precisão no manejo da língua, a exploração das possibilidades da descrição objetiva, a acuidade do olhar investigador e de sua tradução narrativa.

É óbvio que me situo no segundo grupo. Óbvio, também, que considero limitada e intencionalmente restritiva a leitura ideológica que pauta boa parte da recepção a Naipaul. Um tipo de leitura que poderia ser explicada, embora dificilmente justificada, nos anos 1960; não hoje.

Em A máscara da África, Naipaul registra o resultado de uma viagem que durou meses (entre 2008 e 2009) e atravessou seis países da África: Uganda, Nigéria, Gana, Costa do Marfim, Gabão e África do Sul. O início por Uganda é simbólico; o escritor viveu lá na metade dos anos 1960 e agora reencontra, espantado, o país que cresceu incrivelmente nos últimos cinquenta anos.

Seu tema central é a religiosidade - daí o subtítulo Vislumbres das crenças africanas -; por isso, a circulação privilegia lugares sagrados e as conversas com moradores locais valorizam a combinação de formas e experimentações da fé.

Inevitável, portanto, comparar com seus relatos de viagem a países islâmicos, como Entre os fiéis (1981) ou Além da fé (1998). Em A máscara da África, no entanto, há mais matizes e possibilidades religiosas, mais camadas de tempo que se acumulam na constituição da atual e multifacetada percepção do sagrado. 
E, na contramão do que tantas vezes dizem os detratores, nada é esquemático no olhar de Naipaul. A ânsia com que busca as informações, com que analisa cada passo e espaço denota uma visão aguda e interessada em percorrer e compreender o mundo alheio.

Num tempo em que o politicamente correto se traduz na aceitação de tudo -tempo em que a ideologia imprecisa e usualmente enganosa do 'multiculturalismo'-, a capacidade crítica declina. Abrimos mão da interpretação em nome de um suposto respeito à diversidade; respeito tantas vezes falso, que não existe na prática e se limita à constatação da existência abstrata do 'outro'.

Naipaul sabe que, para de fato reconhecer a diferença, é preciso definir a própria perspectiva, expô-la com clareza, assumi-la; evitar o posicionamento ambíguo e exercer a crítica - atividade fundamental para a compreensão.

O leitor de A máscara da África pode, assim, percorrer as plurais crenças africanas através dos olhos de Naipaul. Mas pode, com facilidade, recorrer ao que ele mostra e construir seus próprios significados, estabelecer sua visão particular. E pode, ainda, desfrutar de um relato de viagem amplo, muito bem concebido e desenvolvido, algo hoje incomum. 